\title{
IDENTIFICATION OF ATTITUDES SUPPORTING TOURISM DEVELOPMENT: A CASE STUDY OF THE DERAWAN ISLAND PEOPLE, BERAU OF EAST BORNEO
}

\author{
Zainurossalamia Saida*, Yahya Muhammad Farid \\ Faculty of Economics and Business, Mulawarman University, Indonesia \\ *E-mail: saida.zainurossalamia.za@feb.unmul.ac.id \\ ORCID: 0000-0002-8046-0343
}

\begin{abstract}
This study aims to analyze the influence of residents' welcome to the tourists, state of the local economy, and personal economic benefits to the pro-tourism behavior of the people of Derawan Island, Berau of East Borneo. This research is an explanatory research; i.e. a research that finds out and explains the influence among variables that aims to test a theory or hypothesis. It applies the Smart-PLS 3.0 analysis tool and quantitative path analysis as the research method. The samples of this study were 120 local residents of Derawan Island who were asked to respond to the questionnaire and were also involved in the interview. The findings show that residents' welcome to the tourists, the state of the local economy, and personal economic benefits have positive influence on the Pro-Tourism Behavior of the people of Derawan Island, Berau, East Borneo, with a contribution of Rsquare value of $37.3 \%$. It means that the Pro-Tourism Behavior is affected by residents' welcome to the tourists, state of the local economy, and personal economic benefits of $37.3 \%$.
\end{abstract}

\section{KEY WORDS}

Residents' welcome to the tourists, state of the local economy, personal economic benefits, pro-tourism behavior.

The Indonesian state has an abundant geography bonus that stretches from the tip of Sumatra Island to Papua Island. This makes Indonesia known as a maritime country and also the largest archipelagic country in the world which has a sea area of 5.8 million $\mathrm{km}^{2}$ and around 17,504 islands which are surrounded by a coastline of $81,290 \mathrm{~km}$. The potential of coastal resources owned by Indonesia, among others, are the beauty of coral reefs in shallow sea water, mangrove forests that have biodiversity and various other marine resources such as fish, minerals and high-value mining materials. This huge potential provides considerable opportunities in the development of tourism because it will increase the country's foreign exchange and help economic growth for local residents.

According to Murphy \& Price (2005) tourism is a journey from one place to another, is temporary, and is carried out by individuals or groups as an effort to find balance or harmony and happiness with the environment in the social, cultural, natural, and scientific dimensions. In addition, tourists are every person who travels from their place of residence to visit other places by enjoying the trip from that visit.

Ribeiro et al., (2017) mentioned that tourism has a role as a means to increase contributions in infrastructure development and create jobs where other industries have fewer jobs, especially when unemployment is at a high level. This is certainly in line with the conditions experienced by Indonesia, which has a high unemployment rate. However, Indonesia has a great opportunity for the tourism industry and many natural attractions from the regions or islands in Indonesia, especially tourism maritime or archipelago in all regions of Indonesia, especially on Borneo Island, precisely in Berau Regency, East Borneo Province.

One of the leading tourisms for Berau Regency is Derawan Island. Derawan Island is an island located in Berau Regency, East Borneo. In this archipelago, there are a number of charming marine tourism objects, one of them is the Underwater Park which is in great demand by local and foreign tourists, especially world-class divers. Basically, the desire to 
support tourism from the local population is based on the positive or negative impacts resulted from tourism. Ribeiro et.al., (2017) also explained that tourism also has the potential to trigger changes in community behavior, waning social values and norms, loss of identity, social conflict, shifting livelihoods and environmental pollution.

These things are susceptible to occur in the community as a result of tourism development, but the various negative impacts arising from tourism development can be anticipated by the community itself. These things not only occur in the development of tourism in rice fields, forests, and mountains, but can also occur in coastal tourism areas which are currently focused on becoming tourist destinations by the Regional Government. Determination of the coastal area as a tourist destination is inseparable from the natural beauty and sea charm that most of the sea in Indonesia has; especially Derawan Island, East Borneo.

Tourism development in coastal areas directly or indirectly will have a positive or negative impact. The development of tourism in coastal areas will directly involve coastal communities who mostly work as fishermen. The social characteristics possessed by fishing communities differ from other communities in general. This is caused by differences in the characteristics of the resources faced. This attitude towards positive and negative impacts will determine whether or not local residents will support and tourism.

The attitude of the local population needs to be considered by the parties concerned. This attitude includes an emotional feeling between residents and tourists, reciprocal relationships that do not harm each other, and the extent of involvement of local residents in efforts to develop tourism in their environment. In addition to the positive and negative impacts, the attitude of pro-tourism is also based on how much economic impact is obtained by the local environment in general as well as by each individual.

Research Problems:

- Is Residents' Welcome to the Tourists influencing the Pro-Tourism Behavior of the people in Derawan Island, Berau, East Borneo?

- Is State of the Local Economy influencing the Pro-Tourism Behavior of the people in Derawan Island, Berau, East Borneo?

- Is Personal Economic Benefit influencing the Pro-Tourism Behavior of the people in Derawan Island, Berau, East Borneo?

Research Objectives:

- To find out the influence of Residents' Welcome to the Tourists toward Pro-Tourism Behavior of the people in Derawan Island, Berau, East Borneo;

- To find out the influence of State of the Local Economy toward Pro-Tourism Behavior of the people in Derawan Island, Berau, East Borneo;

- To find out the influence of Personal Economic Benefit toward Pro-Tourism Behavior of the people in Derawan Island, Berau, East Borneo.

\section{LITERATURE REVIEW}

Derawan Island is one of the villages located in the Derawan Island District, Berau Regency, East Borneo Province. Geographically, Pulau Derawan village has administrative boundaries or is surrounded by several sub-districts and also districts; the north of Derawan Island is immediately bordered by Bulungan Regency, the south is bordered by Talisayan District, while the East is bordered by Maratua District and in the west is Tanjung Batu Village of Derawan Islands District. The total area of the Derawan Island village area is approximately 43 hectares in which the majority of its area is sand. Derawan Island village is a village that has an archipelago's topographic form, so that the village itself uses more of its territory for fisheries and tourism.

In 2012, the Indonesian Ministry of Tourism and Creative Economy set Derawan Island as one of the Tourism Villages in Indonesia. With the determination of the status of this Tourism Village, it is expected that the community will be actively involved in the tourism development, which will cause the preservation of ecosystems that live in tourist areas and 
attract tourists to come. Therefore, it requires good synergy from the government, local residents and tourism actors themselves.

However, quoted from www.prokal.berau.com in 2016, tourists coming to Derawan Island experienced a decline. Some hotel and lodging managers claimed that the number of visitors decreased compared to the long Eid holiday in 2015. The decline in the number of visitors even reached 40 to 50 percent. This is certainly a work to think about by the government, the managers of Derawan Island and local residents to re-increase the tourist visit.

One reason of the decreasing numbers of visitors to Derawan Island is the lack of response and awareness of the management and local residents in an effort to support the tourism development in their environment. As quoted from www.beraunews.com in 2016, it shows that many tourists feel dissatisfied with the services shown by the Human Resources businessmen on Derawan Island. This resulted in many tourists who then disseminated their complaints through social media so that poor information quickly spread to the general public.

For local residents, welcoming tourists who come to tourism destinations has become commonplace (Bimonte \& Punzo, 2016). Basically, every local resident will certainly welcome the tourists. It is because the tourists who come will cause a lot of interactions and exchange effects between local residents and tourists, both positive and negative impacts. Therefore, local residents will welcome tourists who come.

Ribeiro et. al., (2017) argues that tourism should focus on the emotional interaction between local residents and tourists and also examine the influence of residents' feelings on the attitude of tourists. It should be carried out so that the tourists feel that there is good interaction from local residents which finally they will feel comfortable.

According to Ribeiro et. al., (2017) many developing countries in the world do not have abundant natural resources and are required to face so many challenges of changing times and economic development challenges that are constantly demanded to make changes to suit the conditions of the times. Therefore, many developing countries then look to the tourism sector as a solution. The thing that is not much different is experienced by East Borneo Province. Basically, East Borneo Province is a rich province in Indonesia from its abundant mining sector, but eventually the mine runs out and currently one of the sectors developed by East Borneo Province is the tourism sector.

According to Stylidis \& Terzidou (2014) the economic state was depressed with a high unemployment rate. Local reesidents care about the local economic state which is perceived to have a more positive attitude about the impact and support of the tourism industry. Stylidis \& Terzidou (2014) also stated that State of the Local Economy is one of the factors that can influence the attitude of residents both positive and negative toward the tourism development. Many residents obtain the economic benefits provided by the tourism. This will certainly create local economic conditions that are good for the environment around tourism.

Table 1 - Indicators of the Research Instrument

\begin{tabular}{|c|c|}
\hline Variables & Indicators \\
\hline Pro-Tourism Behavior (Y) & $\begin{array}{l}\text { The intensity of the hospitality of the people, the preservation of } \\
\text { natural resources of tourism, the provision of information and } \\
\text { experience, becoming a tourism promotion agent, and the } \\
\text { acceptance of negative impacts }\end{array}$ \\
\hline Residents' Welcome to the Tourists $\left(\mathrm{X}_{1}\right)$ & Sense of pride, good treatment and economic contribution \\
\hline State of the Local Economy $\left(\mathrm{X}_{2}\right)$ & $\begin{array}{l}\text { Government contributions, high taxes, improvement in living } \\
\text { standards }\end{array}$ \\
\hline Personal Economic Benefit $\left(\mathrm{X}_{3}\right)$ & $\begin{array}{l}\text { Economic benefit for gamily, large economic benefits, and income } \\
\text { dependence from tourism }\end{array}$ \\
\hline
\end{tabular}

Source: Ribeiro et al., (2017).

Personal Economic Benefit, according to McGehee \& Andereck (2004), is the benefit that each individual receives which is then enjoyed by the individuals themselves. That is, the attitude of supporting tourism for residents is also influenced by how much economic benefits 
are received by each resident in the tourism environment. People who obtain more economic benefits from tourism tend to have a greater positive attitude toward tourism development compared to people who obtain lower economic benefits.

Hypotheses Development. Woosnam (2012) stated that the Residents' Welcome to the Tourists is one of the important indicators that are needed in pro-tourism residents. It is an emotional solidarity relationship between tourists and local residents that serves to measure the attitude of supporting citizens towards tourism development.

Residents' Welcome to the Tourists has three indicators in their measurement; including the existence of a sense of pride, good treatment and economic contribution. It becomes the background of the research to prove the influence of Residents' Welcome to the Tourists towards Pro-Tourism Behavior on Communities around Derawan Island, Berau, East Borneo

$\mathrm{H} 1$ : It is assumed that the Residents' Welcome to the Tourists variable influences the Pro-Tourism Behavior in Communities around Derawan Island, Berau, East Borneo.

According to Stylidis and Terzidou (2014), State of the Local Economy is one of the important things in the factor of residents' supporting attitude toward the tourism development. Stylidis and Terzidou (2014) stated that the economy is depressed by high unemployment. In addition, the existing population is more concerned with the perceived local economic situation so it has a more positive attitude about the impact and support for tourism development.

The State of the Local Economy has three main indicators to measure it; including government contributions, high taxes, and improvement in living standards. It becomes the background of the research prove the influence of State of the Local Economy on ProTourism Behavior in Communities around Derawan Island, Berau, East Borneo

$\mathrm{H} 2$ : It is assumed that the State of the Local Economy variable influences the ProTourism Behavior in Communities around Derawan Island, Berau, East Borneo.

Boley et. al., (2014) stated that Personal Economic Benefit is also an indicator to assess whether the community supports tourism development in their region or not; the greater the individual obtains a big economic benefit, the greater their supporting attitude toward tourism development.

Personal Economic Benefit has three main indicators to measure it; including the economic benefits for families, the creation of large economic benefits, and the existence of income dependence from tourism. It becomes the background of the research to prove the influence of Personal Economic Benefit on Pro-Tourism Behavior in Communities around Derawan Island, Berau, East Borneo.

H3: It is assumed that the Personal Economic Benefit variable influences the ProTourism Behavior in Communities around Derawan Island, Berau, East Borneo.

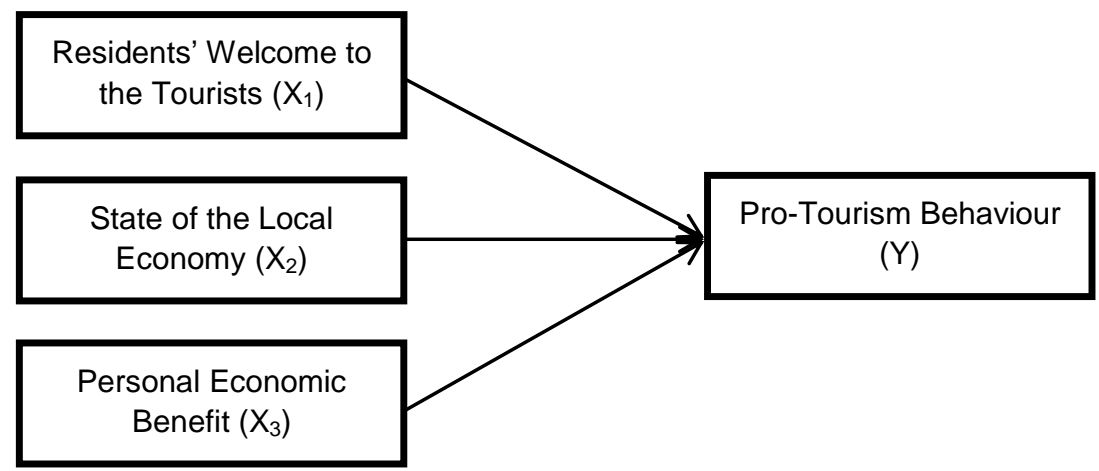

Figure 1 - Conceptual Framework

\section{METHODS OF RESEARCH}

This research is an explanatory research; i.e. a research that finds out and explains the influence among variables that aim to test a theory or hypothesis in order to strengthen or 
reject the empirical theories or studies that have been conducted before. It was continued by testing the hypothesis which means that this study explains causal relationships among variables. This study uses survey techniques by distributing questionnaires and giving them values based on Likert scales with 1-5 value intervals. The research variables consist of three independent variables $(X)$ : Residents' Welcome to the Tourists $\left(X_{1}\right)$, State of the Local Economy $\left(\mathrm{X}_{2}\right)$, Personal Economic Benefit $\left(\mathrm{X}_{3}\right)$, and one dependent variable $(\mathrm{Y})$ : ProTourism Behavior.

The sampling was carried out using a multi-purposive sampling technique that is sampling based on research considerations or based on desired elements or based on certain criteria (Sugiyono, 2009). The population used in this study is the local residents in Derawan Island, Berau, East Borneo, while the sample used is 120 respondents.

This study uses the Smart-PIs 3.0 analysis tool and path analysis method. According to Ghozali \& Latan (2015), path analysis itself consists of two models: the structural model (inner model): a model that explains the correlation between latent variables and measurement models (outer model): a model that explains between indicators with their latent variables. Before conducting the test phase of the two models, the estimation step was carried out by an iteration process to achieve convergent conditions where each indicator of the latent variable has a value of loading factor $<0.05$.

\section{RESULTS AND DISCUSSION}

Based on the iteration process, the Y.4 indicator is 0.399 and the Y.5 indicator is 0.174 , in which both are $<0.50$ so they need to be eliminated.

Table 2 - Loading Factor for Each Construct

\begin{tabular}{|c|c|c|c|}
\hline Variables & Construct & Loading Factor & Description \\
\hline \multirow{3}{*}{$\begin{array}{c}\text { Residents' Welcome to the } \\
\text { Tourists }\left(X_{1}\right)\end{array}$} & Sense of Pride (X1.1) & 0.640 & $>0.50$ \\
\hline & Good Treatment (X1.2) & 0.777 & $>0.50$ \\
\hline & Economic Contribution (X1.3) & 0.755 & $>0.50$ \\
\hline \multirow{3}{*}{$\begin{array}{l}\text { State of the Local Economy } \\
\qquad\left(\mathrm{X}_{2}\right)\end{array}$} & Government Contribution (X2.1) & 0.737 & $>0.50$ \\
\hline & Improvement in Living Standard (X2.2) & 0.837 & $>0.50$ \\
\hline & High Taxes (X2.3) & 0.782 & $>0.50$ \\
\hline \multirow{3}{*}{ Personal Economic Benefit $\left(\mathrm{X}_{3}\right)$} & Economic Benefits for Family (X3.1) & 0.902 & $>0.50$ \\
\hline & Large Economic Benefits (X3.2) & 0.907 & $>0.50$ \\
\hline & Income Dependence from Tourism (X3.3) & 0.884 & $>0.50$ \\
\hline \multirow{5}{*}{ Pro-Tourism Behavior (Y) } & The intensity of the hospitality of the people (Y.1) & 0.716 & $>0.50$ \\
\hline & The preservation of natural resources of tourism (Y.2) & 0.742 & $>0.50$ \\
\hline & The provision of information and experience (Y.3) & 0.801 & $>0.50$ \\
\hline & Becoming a tourism promotion agent (Y.4) & 0.399 & Eliminated \\
\hline & The acceptance of negative impacts (Y.5) & 0.174 & Eliminated \\
\hline
\end{tabular}

Source: Smart-PLS 3.0.

Table 3 - Loading Factor for Each Construct in the Second Iteration

\begin{tabular}{|c|c|c|c|}
\hline Variables & Construct & $\begin{array}{l}\text { Loading } \\
\text { Factor }\end{array}$ & Description \\
\hline \multirow{3}{*}{$\begin{array}{l}\text { Residents' Welcome to the } \\
\text { Tourists }\left(X_{1}\right)\end{array}$} & Sense of Pride (X1.1) & 0.695 & $>0.50$ \\
\hline & Good Treatment (X1.2) & 0.744 & $>0.50$ \\
\hline & Economic Contribution (X1.3) & 0.737 & $>0.50$ \\
\hline \multirow{3}{*}{ State of the Local Economy $\left(\mathrm{X}_{2}\right)$} & Government Contribution (X2.1) & 0.748 & $>0.50$ \\
\hline & Improvement in Living Standard (X2.2) & 0.839 & $>0.50$ \\
\hline & High Taxes (X2.3) & 0.770 & $>0.50$ \\
\hline \multirow{3}{*}{ Personal Economic Benefit $\left(X_{3}\right)$} & Economic Benefits for Family (X3.1) & 0.884 & $>0.50$ \\
\hline & Large Economic Benefits (X3.2) & 0.934 & $>0.50$ \\
\hline & Income Dependence from Tourism (X3.3) & 0.849 & $>0.50$ \\
\hline \multirow{3}{*}{ Pro-Tourism Behavior (Y) } & The intensity of the hospitality of the people (Y.1) & 0.757 & $>0.50$ \\
\hline & The preservation of natural resources of tourism (Y.2) & 0.808 & $>0.50$ \\
\hline & The provision of information and experience (Y.3) & 0.829 & $>0.50$ \\
\hline
\end{tabular}

Source: Smart-PLS 3.0. 
Based on the results of the second iteration it was found that all indicators of latent variables had fulfilled the requirements for convergent conditions which were $>0.50$ so that the study could continue analysis to the measurement model (outer model) and structural model (inner model).

Table 4 - Outer Model Test

\begin{tabular}{|c|c|c|c|}
\hline Variables & AVE & Composite reliability & Cronbach Alpha \\
\hline Residents' Welcome to the Tourists $\left(\mathrm{X}_{1}\right)$ & 0.526 & 0.769 & 0.551 \\
\hline State of the Local Economy $\left(\mathrm{X}_{2}\right)$ & 0.619 & 0.829 & 0.696 \\
\hline Personal Economic Benefit $\left(\mathrm{X}_{3}\right)$ & 0.792 & 0.919 & 0.833 \\
\hline State of the Local Economy $\left(\mathrm{X}_{2}\right)$ & 0.637 & 0.840 & 0.716 \\
\hline
\end{tabular}

Source: Smart-PLS 3.0.

In addition to the convergent value, the construct is also assessed from the Average Variance Extracted (AVE) in which the expected AVE value is $>0.5$. From table 4 , it is known that all AVE values of the research variables meet the requirement because they have values above 0.5 . Furthermore, the Reliability Test is carried out in which the expected value in this test is above 0.7. From table 4, it is known that all variables have a Composite Reliability value above 0.7 . Reliability Tests can also be strengthened by Cronbach Alpha in which the expected value is above 0.6. From table 4, it is known that all variables have Cronbach Alpha values above 0.6 except for the Residents' Welcome to the Tourist variable which has a Cronbach Alpha value of 0.551 .

This analysis is carried out with the aim of obtaining accurate results so that hypothesis testing can be done appropriately. The inner model test is carried out in several steps.

Table 5 - The Coefficient of Determination

\begin{tabular}{|c|c|}
\hline Construct & $\mathrm{R}^{2}$ \\
\hline Pro-Tourism Behavior & 0.373 \\
\hline
\end{tabular}

Source: Smart-PLS 3.0.

Calculating Predictive Relevance $\left(Q^{2}\right)$ can be carried out by:

$$
Q^{2}=1-\left(1-R^{2}\right)=0.373
$$

The magnitude of $Q^{2}$ has a vulnerable value of $0<Q^{2}<1$, in which the closer it is to 1 , the better the model is.

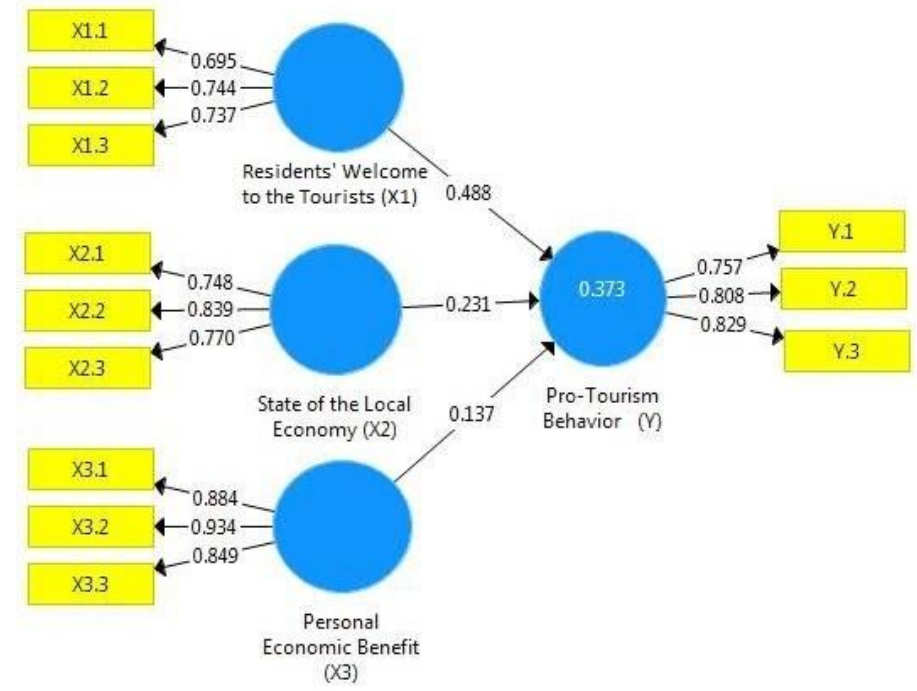

Figure 2 - Structural Model (Source: Smart-PLS 3.0) 
Testing the hypothesis can be seen from the t-statistics and the probability values. Testing hypotheses, with the statistical values, uses alpha 5\% and t-statistics value of 1.96 (Hussein, 2015).

Table 6 - Path Coefficient

\begin{tabular}{|l|c|c|c|}
\hline \multicolumn{1}{|c|}{ Hypotheses } & $\begin{array}{c}\text { Original } \\
\text { Sample }\end{array}$ & $\begin{array}{c}\text { Standard } \\
\text { Deviation }\end{array}$ & $\begin{array}{c}\mathrm{t} \text { - } \\
\text { statistics }\end{array}$ \\
\hline $\begin{array}{l}\text { H1 Residents' Welcome to the Tourists has influence toward } \\
\text { Pro-Tourism Behavior }\end{array}$ & 0,488 & 0,094 & 5,169 \\
\hline $\begin{array}{l}\text { H2 State of the Local Economy has influence toward Pro- } \\
\text { Tourism Behavior }\end{array}$ & 0,231 & 0,099 & 2,330 \\
\hline $\begin{array}{l}\text { H3 Personal Economic Benefit has influence toward Pro-Tourism } \\
\text { Behavior }\end{array}$ & 0,137 & 0,078 & 1,768 \\
\hline
\end{tabular}

Source: Smart-PLS 3.0.

The correlation between Residents' Welcome to the Tourist and the Pro-Tourism Behavior is significant with a statistic score of 5.169 (>1.96). The Original Sample value is positive that is equal to 0.488 which indicates that the Residents' Welcome to the Tourist has positive and significant influence on the Pro-Tourism Behavior. It means that Hypothesis 1 which states "Residents' Welcome to the Tourists influences the Pro-Tourism Behavior in Communities around Derawan Island, Berau, East Borneo" is accepted.

The correlation between State of the Local Economy and the Pro-Tourism Behavior is significant with a statistic score of $2.330(>1.96)$. The Original Sample value is positive that is equal to 0.231 which indicates that the State of the Local Economy has positive and significant influence on the Pro-Tourism Behavior. It means that Hypothesis 2 which states "State of the Local Economy influences the Pro-Tourism Behavior in Communities around Derawan Island, Berau, East Borneo" is accepted.

The correlation between the Personal Economic Benefit and the Pro-Tourism Behavior is not significant with the T-statistic score of $1.768(<1.96)$. The Original Sample value is positive that is equal to 0.231 which indicates that the Personal Economic Benefit has positive and insignificant influence on the Pro-Tourism Behavior. It means that Hypothesis 3 which states "Personal Economic Benefit influences the Pro-Tourism Behavior in Communities around Derawan Island, Berau, East Borneo" is accepted.

\section{CONCLUSION AND SUGGESTIONS}

Residents' welcome to the tourists has positive and significant influence on pro-tourism behavior on communities around Derawan Island, Berau, East Borneo. It shows that if there is an increase in residents' welcome to the tourists, the pro-tourism behavior will also increase; the higher the residents' welcome to the tourists, the higher the pro-tourism behavior. Good treatment from residents to the tourists has been proven to be an indicator that has the strongest value to explain the pro-tourism behavior (the attitude of supporting the tourism) by local residents. Suggestion from the author is that the community or local residents of Derawan Island are expected to continue to be friendly in welcoming and serving the tourists who make a visit. Therefore, it is expected to increase the number of tourist visits to Derawan Island.

State of the local economy has positive and significant influence on pro-tourism behavior on communities around Derawan Island, Berau, East Borneo. It shows that if there is an increase in the State of the local economy, pro-tourism behavior will also increase; the higher the State of the local economy, the more pro-tourism behavior will be. The improvement in living standards, experienced by the resident as a result of tourism and a good local economy, has proven to be the strongest indicator to explain the pro-tourism behavior by local residents. The suggestion from the author for the government is that the government should make a legal provision to set the standard price of tour packages. Later, 
it is expected to reduce the intervention of outsiders who like to change the price of tour packages that burden local business people or residents of Derawan Island.

Personal economic benefit has positive but not significant effect on pro-tourism behavior on communities around Derawan Island, Berau, East Borneo. It shows that if there is an increase in the economic benefits, the pro-tourism behavior will also increase, but it will not affect the pro-tourism behavior. Communities that get more economic benefits from tourism have proven to be one of the most powerful indicators to explain the pro-tourism behavior by local residents. Suggestion from researchers for the government and local residents is to hold socialization or soft skills training about how good ways to be able to utilize the existing tourism resources. Thus, it will again create new jobs and business opportunities for local residents.

Based on the observations, local residents really expect that tourism in Derawan Island will become a destination for both local and foreign tourists. Local residents strongly support tourism development because most of the income and economic future depend on the tourism sector. The residents are willing to provide information to tourists who make a visit and contribute to improving their experience. Therefore, mutual synergy between Local Residents, Village Government, City Government as well as business people and tourists is needed to promote Derawan Island as a tourist destination and also jointly support the development of Derawan Island tourism sector.

\section{REFERENCES}

1. Bimonte, S., Punzo, L. F. (2016), Tourist development and host-guest interaction: An economic exchange theory. Annals of Tourism Research, 58, 128-139.

2. Boley, B.B., McGehee, N.G., Perdue, R.R., Long, P. (2014), Empowerment and Resident Attitdes toward Tourism: Strenghening the Theoretical Foundation Through a Weberian Lens. Annals of Tourism Research. 33-50.

3. Ghozali, I., Latan, H. (2015), Partial least squares: Konsep, teknik dan aplikasi menggunakan program SmartPLS 3.0 untuk penelitian empiris. Semarang: Badan Penerbit UNDIP.

4. McGehee, N. G., Andereck, K. L. (2004), Factors predicting rural residents' support of tourism. Journal of travel research, 43(2), 131-140.

5. Murphy, P. E., \& Price, G. G. (2005). Tourism and sustainable development. Global tourism, 3, 167-193.

6. Prokal Berau. (2016), Jumlah kunjungan Pulau Derawan Menurun, penginapan banyak kosong. $\quad \mathrm{http}: / /$ berau.prokal.co/read/news/44332-jumlah-kunjungan-pulau-derawanmenurun-penginapan-banyak-kosong.html. Accessed on November 17th, 2017.

7. Ribeiro, M. A., Pinto, P., Silva, J. A., Woosnam, K. M. (2017), Residents' attitudes and the adoption of pro-tourism behaviours: The case of developing island countries. Tourism Management, 61, 523-537.

8. Sawega, A. (2016), Wisatawan keluhkan SDM pelaku wisata Derawan http://www.beraunews.com/wisata-budaya/wisata/2122-wisatawan-keluhkan-sdm-pelakuwisata-derawan. Accessed on November 17th, 2017.

9. Stylidis, D., Terzidou, M. (2014), Tourism and the economic crisis in Kavala, Greece. Annals of Tourism Research, 44, 210-226.

10. Sugiyono. (2009), Metode Penelitian Kuantitatif, Kualitatif dan R\&D. Bandung: Alfabeta.

11. Woosnam, K. M. (2012), Using emotional solidarity to explain residents' attitudes about tourism and tourism development. Journal of Travel Research, 51(3), 315-327. 